\title{
Climate Change, Labor Market and Rural Worker Mobility
}

\author{
Murdiansyah Herman ${ }^{1}$, Sunardi ${ }^{2}$, Imam Sumantri ${ }^{3}$ \\ \{murdiansyahuniska@gmail.com¹, sunardibombong@gmail.com²,imamfoz@gmail.com³ \\ Universitas Islam Banjarmasin, Jln. Kayu Tangi, Banjarmasin, Indonesia ${ }^{1}$ \\ Department of Government Science, Hasanuddin University, J1. Perintis Kemerdekaan KM 10, Makassar, \\ Indonesia $^{2}$
}

\begin{abstract}
This worksheet will look at how the impact of climate change does on the labor market and the rural worker mobility. The question departs from the lack of academic debate about the relationship between climate change and the labor market, and the rural worker mobility. The main stream, which has so far discussed the labor market and the rural worker mobility, has focused more in the aspect of access to ownership of production facilities in the rural area. The argument is that the mobility of the community from the rural area to the urban area is due to problems in the rural area where the community does not have sufficient production facilities, in this case the ownership of adequate production facilities. This argument is not entirely wrong, but needs to be discussed further. This worksheet would like to show if there are other aspects in the village besides the issue of access to production facilities. This article sees that the labor market and the rural worker mobility from rural areas to urban areas are also driven by climate change.
\end{abstract}

Keywords: Climate change, Rural worker, Labor mobility, Labor Market

\section{Introduction}

Climate Change has become one of the themes that has over the past few years been bustling in academic debates. One of the issues often associated with climate change is the condition of agriculture in rural areas [1]-[7]. The question of the impact of climate change on agricultural livelihoods is a question that is generally public. At least for several decades the question seems relevant to continue to be discussed by scholars [8]-[11]. This can be seen from the attention of scholars in several parts of the world. In Europe, the issue of climate change related to agriculture is becoming an issue that is widely discussed by scholars. One of them is the problem of drought which is seen by scholars in Europe as a political plague that has major implications for the lives of villagers. Drought has had a domino effect on workers' mobility, while at the same time a prolonged drought has increasingly marginalized women from the rural development agenda [3]. 
Likewise, in Africa, climate change has changed the style of agricultural production in rural communities, especially during the prolonged summer. The hot season has hampered agricultural activities and even failed to harvest, which has a dominant impact on the problem of hunger [5]. While in Mexico, climate change has had a very serious impact on the decreasing workforce available in the countryside [7] and finally in Asia climate change has had an impact on the labor deficit [12].

The other side that is no less important is the link between climate change and the labor market in rural areas. This academic position is apparently still rarely seen by scholars. Apart from the attention of many scholars focused on the issue of agricultural productivity, farm labor in the agricultural sector or farmers Petty Commodity Production (PCP) are the focus of research that is still largely ignored [13], [14]. Whereas in Indonesian context, the development of peripheral capitalism with the characteristics of rural production is largely based on the agrarian sector. According to the BPS data, as many as 33,487,806 Indonesians depend on the agricultural sector and more than $50 \%$ of that number work as agricultural labors [15]. The situation is more complicated, because most farm workers live in rural area.

At the same time, the literature on climate change with labor market flexibility in rural areas for the context in Eastern Indonesia is very limited. Some agrarian studies mostly took place with observational sites in Java and Sumatra [16], [17]. However, there are other studies like the one Scahrauwers [18] did in North Sulawesi, but this research used the perspective of Marxist anthropology, so that the analysis built by banging technical issues like climate change was very minimum. On the other hand, the lack of research that took place in Eastern Indonesia, theoretically failed to explain climate change with regard to the workers mobility, especially in Eastern Indonesia. In fact, one of the parts in Indonesia which accounts for the highest poverty rate is in Eastern Indonesia.

This study tries to take the gap left by previous studies of the rural labor market, with the argument that climate change that is taking place has a significant impact on the labor market in rural areas, especially in the agricultural classes. Then, the next domino effect on labor market flexibility changes is the high mobility from rural to urban and vice versa.

\section{Research Method}

The research took place in Panaikang Village, Pattallassang District, Gowa Regency. This location was chosen based on the consideration that this sub-district is one of the buffer subdistricts located in the golden triangle of South Sulawesi, which connects Gowa-Makassar and Gowa-Maros. Maros is an industrial development area in Eastern Indonesia, while Makassar is an industrial center as well as an area populated by the service sector.

In addition, Makassar as the capital of South Sulawesi Province is still developing. Among the developments is housing construction, which most workers are supplied from Gowa Regency, one of them from Pattallassang. This situation is very strategic to see how the mobility of the population from the village (Pattallassang) to industrial centers such as Makassar and Maros does.

Data collection was done by live-in observation. The author was well-understood about the conditions in the village, because the writer lived and grew in the research location. This then 
made the interview was not done by the author, considering the observed pattern that has been going on for a very long time. In several observations, the author also directly experienced the process and social activities carried out by the community, such as agricultural and migratory activities. Finally, in order to strengthen the data and field findings, this study also conducted a literature study. It aimed to conduct comparative studies related to mobility patterns that occurred elsewhere. Comparative studies were carried out by collecting several articles and research results that were relevant to the research theme. Then, in the last part, this study also used official reports from the government as well as the results of releases from institutions or institutions that are credible, such as the Central Statistics Agency [15].

\section{Result and Discussion}

The tendency of studies on climate change on the one hand and agrarian on the other, is still fragmented. This is seen in several studies related to climate change and agrarian issues. As far as the author's observations, the current study on climate change is still concentrated on ecological issues. As mentioned earlier, several studies on climate change that occurred in the world show that many studies on climate change depart from the point of more argumentation on ecological aspects. One of them is the findings of Barry and Paterson in the UK who try to uncover climate change to be a driver of discourse change on a global scale [3]. Barry and Paterson write very clearly that the discourse that has developed in the world in recent years, is inseparable from the influence of climate change. Most people ultimately focus on the environment or environmental politics.

One scholar even wrote that climate change has threatened people's lives. Climate change has caused tens of hectares of food to fail in production. Situations that then create the threat of starvation can afflict people [1]. More extreme observations about climate change are made by Bohle, Downing and Watts. These scholars see if climate change is happening not only have an impact on ecological damage. However, the most crucial thing is that climate change has cut agricultural production.

More than that, according to Denton climate change is increasingly cornering women. Sustainable development agendas for women are becoming increasingly biased [2]. This situation is a result of climate change which makes the double burden experienced by women increasingly heavy. During this time, structurally women have been thrown from the political stage whose impact on women's political existence. It does not stop there; the situation becomes more difficult when a drought hits a country. Women have to bear heavier burdens, are not accommodated politically and then forced to accept the effects of climate change. Unfortunately, the attention of many people is to make women's political agendas and defenses in the face of climate change an absent political debate in the debate. The sustainable development agenda on the impacts of climate change is more aimed at men. Denton further explained this situation because from the beginning men had greater political space compared to women.

In Mexico climate change has also impacted population mobility. In Mexico, hot weather is an obstacle for community activities, such as agricultural activities. As a result of extreme weather, not a few of the villagers in Mexico who then chose to leave the village and then to the city. In the 
City, villagers are looking for alternative jobs. This makes the majority of villages in Mexico experience a labor deficit when they are in the summer. In fact, according to Jessoe and Manning[7], it has been noted that as much as $14 \%$ of the rural labor deficit is due to extreme heat.

Although some of the findings in various countries above cannot be used as evidence to generalize as a global event. Especially if it comes to concluding that climate change has had an impact on the workers mobility in the world. However, it is important to note the findings of McLeman and Smit [4] who have seen the phenomenon in Africa as a phenomenon that at least helps readers to see patterns that occur in African society after climate change._It is true that climate change does not generally encourage population mobility and has a wider impact on the labor market. However, one thing is certain from the findings of McLeman and Smit [4] if climate change is interpreted differently by the people in the village. Different perceptions as the impact of different social strata, like the level of education in the village. This looks very simple, but has considerable implications. Imagination of rural communities about the impact of climate change depends on the level of awareness and formal abilities of rural communities. McLeman and Smit's [4] findings show, the higher one's formal ability in this case formal education, the imagination about the impact of climate change is also greater, conversely rural communities who have relatively lower education will experience obstacles in seeing climate change that will occur.

This means that, even though climate change takes place naturally, it must still be interpreted as something that can be responded back by the rural community. So it becomes very relevant what is then said by Guivarch [6] who sees if the allocation for mitigation costs especially those related to climate change becomes difficult to predict. This is in line with the community's response, especially in labor market conditions. Guivarch [6] sees that the labor market has an economic position that is very calculated in making financing schemes on mitigation in a country.

In line with Guivarch, on another occasion McLeman and Smit [4] also indirectly built an argument which see that climate change as a natural phenomenon, took place outside human intervention. It's just that, on a certain side of climate change has forced most human social activities to change. McLeman and Smit's findings see if climate change forces rural communities to migrate to big cities. This evidence once again shows that climate change that has occurred in many places in the world has encouraged people to take political action, one of which is by migrating [4]. Migration in this case is not only understood as the process of moving people from villages to cities, but more than that in other contexts seen by McLeman and Smit [4] migration occurs as a form of community adaptation to climate change in a place.

On the other hand, agrarian studies have also so far looked more at rural labor markets and the mobility of agricultural labor is always in conflict with ownership of production facilities. This argument at least comes from the Marxist tradition, which then looks at the rural labor market and labor mobility due to access to lame land tenure. Some people control more land, while others only control enough land for sub-systems. Those who control more land have the opportunity to sell small workers, as well as opportunities to compete in the city as construction workers are very small. While for those who own a small amount of land, the opportunity to sell their energy is also widely open.

It seems that this big thesis is not irrelevant, but in certain contexts it is important to re-discuss. Author's observations in the villages of Pattallassang, Gowa, South Sulawesi. The tendency of both farmers who own large tracts of land and those who do not own land or with small land ownership have the same opportunity to be absorbed in the labor market, and become informal 
workers. As an illustration, in Pattallassang the land area is approaching 6,000 (Ha). This figure is not an exact figure, because every year new land clearing takes place which makes the land number also experience a significant increase.

Table 1. Land Condition Data in Pattallassang

\begin{tabular}{llcc}
\hline \multicolumn{1}{c}{ Type of Land } & Land Classification & Luas (Ha)/2017 & Luas (Ha)/2018 \\
\hline Dry Land & Garden & 1.862 & 1.960 \\
& Field & 281 & 290 \\
& Plantation & 2.292 & 3.350 \\
Total & Civilians Forest & 25 & 25 \\
Field land & & $\mathbf{4 . 4 6 0}$ & $\mathbf{5 . 6 0 0}$ \\
Total & Two-times planting & 657 & 835 \\
\hline
\end{tabular}

Source: [19]

However, even though the land area number has touched 6,000 (Ha), it is not a guarantee that villagers in Pattallassang will not migrate to the city. More land types are dominated by dry land whose production activities depend heavily on rainfall. A total of 5,600 (Ha) of the total land in Pattallassang is dry land. This complicates the agricultural productivity of the community. The situation was then aggravated by a long drought. Reflecting on the 2018 weather report released by BPS, shows that until November the rainfall in the Gowa Region in general, Pattallassang in particular was very low. Rainfall is only in the range of $24 \mathrm{~mm}$. In fact, there is almost no rain that lasts from October to September. Meanwhile, in October to September it coincides with the community agricultural cycle in Pattallassang. This means that extreme hot weather makes some land fail to produce production.

Table 2. Rainfall in Gowa

\begin{tabular}{cc}
\hline Month & Rainfall $(\mathbf{m m})$ \\
\hline January & 1.123 \\
February & 469 \\
March & 319 \\
April & 340 \\
May & 162 \\
June & 284 \\
July & 202 \\
August & - \\
September & 0 \\
October & 24 \\
November & 164 \\
December & 756 \\
\hline
\end{tabular}


In effect, the drought forced the community to leave agricultural land in the village. Then choose the city with the aim of getting alternative work while waiting for the rainy season. For the context that occurs in Pattallassang and villages in Sulawesi in general, most people will choose Makassar as their destination. This is not surprising, considering that in Eastern Indonesia, Makassar city is one of the cities with very dense industrial activities. Makassar is even known as an industrial city. A total of 99 industrial units are operating in Makassar. This figure shows Makassar as the city with the largest industrial activity in Eastern Indonesia.

Table. 3 Industries in South Sulawesi

\begin{tabular}{lccc}
\hline \multicolumn{1}{c}{ Regency / City } & Medium Industry & Large Industry & Total \\
\hline Bulukumba & 1 & 4 & 5 \\
Bantaeng & - & 2 & 2 \\
Jenkneponto & - & 2 & 2 \\
Takalar & 4 & 11 & 15 \\
Gowa & 3 & 9 & 12 \\
Sinjai & - & 2 & 2 \\
Maros & 7 & 10 & 17 \\
Pangkep & 15 & 10 & 25 \\
Barru & 1 & 1 & 2 \\
Bone & 2 & 6 & 8 \\
Wajo & - & 22 & 22 \\
Sidrap & - & 2 & 2 \\
Pinrang & 2 & 31 & 33 \\
Enrekang & & 1 & 1 \\
Tator & - & 2 & 2 \\
Luwu Utara & - & 2 & 4 \\
Luwu Timur & 2 & 2 & 1 \\
Toraja Utara & 0 & 1 & 99 \\
Makassar & 40 & 59 & 2 \\
Pare-pare & - & 2 & 17 \\
Palopo & 1 & 16 & 2 \\
\hline
\end{tabular}

Source: [21]

Unfortunately, formalization in the world of work often prevents the Pattallassang community from being absorbed in the industry in Makassar. In the end, in Makassar the villagers complained about their fate as informal workers. This work is carried out during the dry season, and during the rainy season construction workers return to the village to cultivate agricultural land.

This cycle takes place every year, so the authors see every climate change, especially entering the dry season, the labor market in the village burst and the labor market overflows are finally channeled as construction workers in the city of Makassar. This is confirmed by data released by BPS, which shows fluctuations in the labor sector, especially in the informal sector[15]. 
Table 4. Population Works by Sector in South Sulawesi

\begin{tabular}{ccc}
\hline Year & Formal & Informal \\
\hline 2015 & 36,95 & 63,05 \\
2016 & 35,11 & 64,89 \\
2017 & 37,63 & 62,37 \\
2018 & 36,99 & 63,01 \\
\hline
\end{tabular}

Source: [15]

This indication shows that the informal works in the city happens along the extreme dry seasons in the village, which causes most of the farmers are in difficulties of land management.

\section{Conclusions}

The mainstream of the Marxist tradition which always places the labor market and the rural workers mobility in rural areas by linking to land tenure seems to be discussed again. This finding shows that the labor market and the rural workers mobility are not always associated with land tenure. In certain contexts, there are technical issues which are also important to be seen as driving the job market and working mobility, such as prolonged drought. Field findings show that prolonged drought is one of the most crucial causes of the labor market situation and the rural workers mobility. Especially for villages where the state of agricultural production still relies on rice fields from rain-fed water.

With a long drought which was then strengthened by the state of agriculture that still relies on rain water, making agricultural land in the village becomes unproductive. As a result, extensive land tenure also does not mean anything. On the contrary, in the village the tendency of those who do not have land actually has a much better economic opportunity.

\section{References}

[1] H. G. Bohle, T. E. Downing, and M. J. Watts.: Climate change and social vulnerability. Glob Environ. Chang. Vol. 4.pp. 37-48 (1994)

[2] F. Denton,.: Climate change vulnerability, impacts, and adaptation: Why does gender matter?.Gend. Dev.Vol. 10.pp. 10-20 (2002)

[3] J. Barry and M. Paterson.: Globalisation, ecological modernisation and new labour. Polit. Stud., vol. 52.pp. 767-784 (2004)

[4] R. McLeman and B. Smit.: Migration as an adaptation to climate change. Clim. Change. Vol. 76.pp. 31-53 (2006)

[5] T. T. Deressa, R. M. Hassan, and C. Ringler.: Perception of and adaptation to climate change by farmers in the Nile basin of Ethiopia. j Agric. Sci.. Vol. 149.pp. 23-31 (2011)

[6] C. Guivarch, R. Crassous, O. Sassi, and S. Hallegatte.: The costs of climate policies in a second-best 
world with labour market imperfections. Clim. Policy.Vol. 11.pp. 768-788 (2011)

[7] K. Jessoe, D. T. Manning, and J. E. Taylor.: Climate Change and Labour Allocation in Rural Mexico: Evidence from Annual Fluctuations in Weather. Econ. J. Vol. 128.pp. 230-261(2018)

[8] B. Rosanne DArrigoa and Rob Wilsona.: El Nĩno and Indian Ocean influences on Indonesian drought implications for forecasting rainfall and crop productivity. Int. J. Climatol. Vol. 29.pp. 317319 (2009)

[9] A. M. and F. C. Stefanos A. Nastis1.: Climate change and agricultural productivity. African J. Agric. Res. Vol. 65.pp. 709-713 (2012)

[10] U. L. C. Baldos and T. W. Hertel.: Global food security in 2050 The role of agricultural productivity and climate change,Aust. J. Agric. Resour. Econ., Vol. 58. pp. 554-570 (2014)

[11] R. Caruso, I. Petrarca, and R. Ricciuti.: Climate change, rice crops, and violence Evidence from Indonesia, J. Peace Res Vol. 53.pp. 66-83 (2016)

[12] S. Savary, N. P. Castilla, F. A. Elazegui, and P. S. Teng.: Multiple effects of two drivers of agricultural change, labour shortage and water scarcity, on rice pest profiles in tropical Asia, $F$. Crop. Res. Vol. 91.pp. 263-271 (2005)

[13] B. Harriss-white and B. Harriss-white, "Labour and Petty Production. Vol. 45. pp. 981-1000.

[14] B. Harriss-White.: Labour and petty production, Dev. Change, Vol. 45.pp. 981-1000 (2014)

[15] BPS.: Laporan Bulanan Data Sosial Ekonomi (2018)

[16] J. F. Mccarthy.: The Journal of Peasant Studies Processes of inclusion and adverse incorporation : oil palm and agrarian change in Sumatra, Indonesia change in Sumatra, Indonesia.pp. 37-41 (2010)

[17] A. L. and C. Warren.: The State, The People And Their Mediators The Struggle Over Agrarian Law Reform In Post-New Order Indonesia (2014)

[18] A. Schrauwers.: Let's party state intervention, discursive traditionalism and the labour process of highland rice cultivators in central Sulawesi, Indonesia, J. Peasant Stud., Vol. 25.pp. 112-130 (1998)

[19] BPS: Kecamatan Pattallassang Dalam Angka 2019 (2019)

[20] BPS : Gowa Dalam Angka (2018)

[21] BPS.: Direktori Industri Sedang Dan Besar Provinsi Sulawesi Selatan (2018) 